\title{
LEVEL OF PRIMARY SCHOOL TEACHERS' EXTRINSIC AND INTRINSIC MOTIVATION AND PERFORMANCE IN SINDH
}

\author{
By \\ Farida Shaikh* \\ Muhammad Ismail Saad** \\ Muhammad Ilyas Bhutto***
}

\begin{abstract}
This mixed study examined the existing level of primary school teachers' perceived intrinsic and extrinsic motivation and their performance assessed through respective head-teachers. Data was collected through adapted teachers' and head-teachers' questionnaires having both Likert-scale items and open-ended questions. Teachers' questionnaire involved 38 (11=intrinsic motivation, 14 =extrinsic motivation) and three open ended questions within the same questionnaire used for obtaining qualitative data. They asked for teachers' insights into existing problems and the measures to improving teachers' motivation and performance; whereas, head-teachers' questionnaire implicated 13 Likert-scale items asking for respective performance of the teachers. Overall internal consistency of the tool was measured through Cronbach's alpha which stood good (.82). The alpha values stood at .89, .74 and .85 for intrinsic motivation, extrinsic motivation; and teachers' performance respectively. The multi-stage random sampling involved 348 teacher-respondents and 40 headteachers of District Hyderabad, Sindh. Data was analyzed through SPSS package of 16.00 for descriptive statistical analyses at 0.05 confidence-intervals. Descriptive statistics revealed that teachers ranked their intrinsic motivation better (mean ranged1.62 to 2.18 for 11items) against extrinsic motivation (mean ranged from 2.50 to 3.97 for 14 items). Teachers' 13 performance items did not catch supporting evidence i.e. means ranged from 1.93 to 3.97 (with 2.82 mean of means) which is disappointing one.
\end{abstract}

Key words: intrinsic motivation, extrinsic motivation, primary school teachers' performance.

\footnotetext{
*PhD student, Faculty of Education and Learning Sciences, Gulshan Campus, Iqra University, Karachi

**Dean Faculty of Education and Learning Sciences, IQRA University, Gulshan Campus, Abid Town, Karachi

***Assistant Professor, Government Boys Degree College, Sehwan
} 


\section{Introduction}

Teacher motivation has grown a vital topic in communicating knowledge and skills to students at all levels. Motivated and satisfied teachers generally are more creative and influencing regarding learners' academic productivity and achievement (Mertler, 1992). Motivation leads an individual's behaviors to the fulfillment and satisfaction of desired objectives (Analoui, 2000). Generally, in working contexts motivation could be classified into two categories - intrinsic and extrinsic (Sansone \& Harackiewicz, 2000).

The former i.e. intrinsic motivation emerges from inner-self or within an individual; it positively and greatly influence one's action, achievement, and continuity (Ryan \& Deci, 2000). On the other hand, the extrinsic or environmental motivation emerges from the attainment of external benefits including financial reward or pay, tangible rewards, social respect and feedback besides many others. Many studies since Thorndike (1911) ranging from pure experimental to field observations like Emery Air Freight research (Hamner \& Hamner, 1976) were conducted under the influence of behaviorist's school of thought; they manipulated extrinsic reinforces or motivators or their related situations or contingencies and found increase in motivation and performance of individuals; for example increase in regularity and punctuality in attendance, increase in time-task or engagement of work, increase in sale, per unit cost-reduction as compared to the value of added extrinsic rewards, increase in the quality of process or services and products, and increase in sale and customer services (Komaki, 1982).

Contrastingly, intrinsic motivation prevails if the behavior of an individual is performed not for extrinsic or environmental rewards but for the satisfaction attained while being engaged in specific task on its own. This idea was an open challenge and resistance to behaviorist's school of thought and it can be traced back to the works of White (1959) regarding competitive and effective motivation.

Different works form different researchers (for example Maslow, 1943; and Alderfer, 1969) paved way for different aspects of intrinsic motivation. Some of the classical perspectives of intrinsic needs involved: teachers' job-satisfaction, enjoyment gained while engaged in a profession/task i.e. teaching, the demanding and viable nature of profession or teaching, social respect and recognition, professional development, and a sense of having power over others. On the other hand, studies on extrinsic motivation led to its fundamental aspects like provision of periodic wage or salary, free residence, free food, additional related allowances, free health facilities or care, admissibility of leave for justified absence, and provision of advance salary etc.

Presently, teachers' job-performance draws out great concern in every society. Hornby (2000) cites Oxford Advanced Learner's Dictionary to define performance. According to it, performance is the acting in an expected way or execution of actions so that set targets or objectives could be achieved (Hornby, 2000).

Therefore, teachers are responsible for their students' learning taking place in or outside the class. Teaching involves planning for lessons and effective utilization of teaching resources, teaching methods and techniques, measurement of students' achievement besides timely guiding and counseling students in their crucial matters and ensuring students' active participation in co-curricular activities. It means that teachers' jobperformance directly relates and integrates all above aspects of teaching and is holistic in nature and is not limited to classroom or school premises but extends their learning beyond classroom or school i.e. at home or other place of society. In this study, the researchers assessed teachers' performance through their respective head-teachers in 13 areas: maintaining teachers' regularity and punctuality at the school; planning for their lessons; administering students' achievement tests; marking of above achievement tests; 
participating/helping in co-curricular activities; giving feedback regarding students' assessment; taking interest in accepting additional responsibilities related to school affairs; taking and ensuring students' attendance; ensuring learner friendly teaching methods and resources; avoiding physical punishment; checking students' cleanliness i.e. nails, uniform etc; giving home work; covering prescribed course of study; and overall performance.

The Pakistani public education system involves five distinct levels: primary (grade15), middle (grade6-8), secondary (grade9-10), higher secondary (grade11-12) and higher/professional education (graduate education and advanced degrees). According to Government of Pakistan, there are157,360 primary schools with a teaching force of 466,451. The students' enrolment in primary schools increased from 18.468 million in 2008-09 to 18.756 million in 2009-10 with a total population of over 180 million (Economic Survey, 2010-11). In third world countries like Pakistan teachers' motivation and extrinsic incentives are found correlated, which means that when teachers' physiological and safety needs are satisfied they tend to be more motivated.

\section{Local Studies on Teacher Motivation}

The teacher motivation remains central in the teaching job performance debates. There are different perspectives about teacher motivation in Pakistan where teachers are weakly motivated due to a combination of low morale and job dissatisfaction, low incentives, and poor controls and other behavioral sanctions. As a result, standards of professional behavior and performance are low and falling.

According to Save the Children (2011), the developing countries including Pakistan conducted a detailed teachers' survey mostly based on Maslow's needs and motivation theory. It pointed out through eight categories that most of the teachers show a negative trend in their motivation to render their services for eight possible causes falling into poor extrinsic and intrinsic motivational areas:

Extrinsic motivational weaknesses:

- Workload and challenges (increasing workload day by day)

- Remuneration and incentives (low and irregularly paid salaries)

- Accountability (weak or little accountability)

- Institutional environment (vague and changing/unstable policies due to unstable political governments and poor management)

- Learning material and facilities (poor learning material and facilities)

Intrinsic motivational weaknesses:

- Recognition and prestige (decreasing social respect and status)

- Career development (teaching as a second or even last choice for competing candidates)

- Voice (teachers are not heard in policy and administrative matters) (p. 3).

In his quasi-experimental study on the public sector ninth graders, Bhutto (2011) also found that extrinsic social reinforcers (smile, good verbal remarks, pat on the back, students' clap, teacher's clap, star of the day) significantly and positively contributed toward better academic learning achievement as compared to the control group taught through traditional teaching that generally involved dictation of questions and answers and use of verbal and physical punishment (pp, 71, 77).

Nasser Ud Din, Tufail, Shereen, Nawaz, and Shahbaz (2012) surveyed through very small sample of 40 secondary school teachers of Kohat, Pakistan about the factors affecting motivation in rendering prescribed teaching services. Through measures of central tendency the authors found that financial (extrinsic or tangible factors) rewards and incentives stood 
primary contributors toward teachers motivation; on the other hand, the socio-status, examination-stress, and teaching as a first choice relatively less affected teachers' motivation. They recommended better salary package for public sector teachers (p. 442-443).

Atta and Jamil (2012) surveyed through 20 items questionnaires from 400 (200 each for males and females) secondary school students. Their study aimed at investigating the effect of students' motivation and parental influence on students' achievement. They found through measures of central tendency and Pearson's correlation that parental influence and students' attainment had strong positive and greater correlation (0.89) than that of students' own motivation and attainment which was found to be moderate (0.67) (p. 430). The researchers targeted to find out the effect of the two predictors i.e. intrinsic and extrinsic motivation; however, they only found simple correlation which did not measure their effect.

Nadim, Chaudhry, Kalyar, and Riaz (2012) conducted their study to determine the effect of intrinsic and extrinsic motivation on college teachers' job-satisfaction from a sample of 500 respondents (250 each for males and females) through self developed five-point Likert scale questionnaires in the context of Punjab, Pakistan. The data were analyzed through Structural Equation Modeling (SEM) technique using Analysis of Moment Structures (AMOS) 19.0 software. The research results reveal that there is statistically significant relationship between intrinsic motivational factors (opportunities to acquire new skills, promotion opportunities, participation in decision making, autonomy, recognition) and teacher job satisfaction. Similarly, statistically significant relationship was also found between extrinsic motivational factors (salary, work environment, relationship with seniors, reward, and feedback) and teacher job satisfaction. However, teacher job satisfaction is largely caused by intrinsic motivational factors (39\%); while extrinsic motivational factors contribute (12\%) to teacher job satisfaction. (p. 29)

Salma and Sajid (2012) in their study involving different levels of teachers concluded that teachers of Kotli (Azad Jamu Kashmir District) were found low-motivated and dissatisfied with their job. The study pointed out crucial factors causing low motivation and dissatisfaction of teachers: teachers were commonly dissatisfied with income, salary, and promotion criteria; teachers showed concern over political involvement in their recruitments, postings and transfers; larger class size (too many students) also undermined job-satisfaction of teachers; lack of subject specialists in high schools demotivated other teachers that were forced or unwillingly teach those subjects; poor accountability at institutional level was one of the major issues; and poor involvement in administrative affairs and decision making negatively affect teachers' job-satisfaction and performance (p. 64).

\section{Purpose of Study}

The study was aimed at examining the existing level of primary teacher's perceived intrinsic and extrinsic motivation and their peryolmacc and through respective head teachers.

\section{Research Questions}

1. What is the existing level of the intrinsic motivation among public sector primary school teachers of District Hyderabad, Sindh?

2. What is the existing level of the extrinsic motivation among public sector primary school teachers of District Hyderabad, Sindh?

3. What is the existing level of the performance of public sector primary school teachers of District Hyderabad, Sindh as perceived by their respective head-teachers?

4. How can we improve the performance of public sector primary school teachers? 


\section{Methodology}

This study involved survey method using both quantitative data (Likert-scale items) and qualitative approach (open-ended questions asking for the ways to improve teachers' motivation and performance). The data was collected from both male and female public sector (Government-run) primary schools across rural and urban strata of Hyderabad district. The study involved a cross-sectional survey for collection of data through questionnaires to gain insights into description, perceptions, and beliefs at any single point in time (White, 2000).

Intrinsic motivation was measured through teachers' job-satisfaction, internal satisfaction while teaching, teaching as competitive and challenging task or job, recognition and respect form society, career advancement, control over others, and teaching as one's aim of life. Whereas, in this study extrinsic motivation was measured through financial benefits and rewards received for the fulfillment of teaching job as a public sector primary school teacher. The extrinsic motivators involved monthly salary, housing or accommodation, food, allowances, advance payment of salary, leave in case of absence, and medical facilities or allowance paid.

\section{Population and Sampling}

The respondents of the study included public sector primary schoolteachers (PSTs) and head teachers. After selecting 40 representative schools regarding gender and location (rural and urban) as a first step of multi-stage sampling, the simple random sampling was used to select the required number (348) of PSTs; additionally above 40 head-teachers were selected as respondents to determine their respective teachers' performance. The size of sample was calculated using on-line sample size calculator. The appropriate sample to existing population (3684 PSTs) appeared to be 348 teachers. Specific attention was paid to ensure proper representation of the respondents regarding gender and location. The process of simple random sampling involved writing names of all respondents of 40 schools on separate pieces of paper; they were folded and put in a box and mixed; a draw was picked at random without replacement to select the respondents (PSTs and head-teachers). Table 1 presents targeted population and quantitative sampling:

Table 1

Targeted Population and Quantitative Sampling

\begin{tabular}{|c|c|c|c|c|c|}
\hline \multirow{3}{*}{ Statistic } & \multicolumn{4}{|c|}{ Population } & \multirow{3}{*}{$\begin{array}{l}\text { Total } \\
(\mathrm{N})\end{array}$} \\
\hline & \multicolumn{2}{|c|}{ Rural } & \multicolumn{2}{|c|}{ Urban } & \\
\hline & $\mathbf{M}$ & $\mathbf{F}$ & $\mathbf{M}$ & $\mathbf{F}$ & \\
\hline $\begin{array}{l}\text { PSTs } \\
\text { (Population) }\end{array}$ & 927 & 268 & 1195 & 1294 & 3684 \\
\hline $\begin{array}{l}\text { PSTs } \\
\text { (Sample) }\end{array}$ & 87 & 24 & 115 & 122 & 348 \\
\hline $\begin{array}{l}\text { Head-teachers } \\
\text { (population) }\end{array}$ & 380 & 80 & 197 & 120 & 957 \\
\hline $\begin{array}{l}\text { Head-teachers } \\
\text { (Sample) }\end{array}$ & 19 & 05 & 09 & 07 & 40 \\
\hline
\end{tabular}




\section{Research Tool}

Two types of questionnaires were used during collection of primary data from the public sector primary school teachers 348 and their respective head-teachers 40 .

Teachers' questionnaire involved 43 items divided in three sections: demographic (15), 25 items on five-point Likert scale (11 and 14 for extrinsic motivation), and open-ended (03). The head-teacher's questionnaire involved 13 Likert-scale questions-13 items. Both the teachers' and head-teachers' questionnaires involved a unique serial number/code along with the name of the teacher; the researcher carefully distributed the portion asking for the performance of the teacher(s) (or head-teacher's questionnaire) to the respective headteacher(s) so that the effect of intrinsic and extrinsic motivation could be determined on their performance.

\section{Pilot Testing}

To ensure validity of instruments, the instruments were developed under close guidance a five member panel of the professors of Iqra University with 10-20 years postdoctorate teaching/research experience. After the questions were designed, they were pilottested on 20 respondents to identify ambiguous questions in the instruments.

\section{Internal Consistency}

Internal consistency between .7 and .8 is considered acceptable and is good between .8 and .9. Internal consistency was calculated for different parts of the questionnaire through Cronbach's alpha values. The alpha values stood at .89 for 11 items of intrinsic motivation; .74 for 14 items of extrinsic motivation; and .85 for 13 items of teachers' performance. The overall Cronbach's alpha was found to be .82 which corresponded to "good" internal consistency reliability of the instrument.

\section{Results}

The study showed following results;

Table 2

Descriptive Statistics of the Demographics

\begin{tabular}{lcccccc}
\hline \multicolumn{1}{c}{ Demographic Variable } & $\mathrm{N}$ & Minimum & Maximum & \multicolumn{2}{c}{ Mean } & \multicolumn{2}{c}{ Std. Deviation } \\
& Statistic & Statistic & Statistic & Statistic & Std. Error & Statistic \\
\hline Age & 348 & 2 & 5 & 4.34 & .045 & .839 \\
Location & 348 & 1 & 2 & 1.68 & .025 & .467 \\
Marital Status & 348 & 1 & 3 & 1.96 & .022 & .407 \\
Gender & 348 & 1 & 2 & 1.42 & .026 & .494 \\
Highest Acad. Qualification & 348 & 1 & 5 & 3.14 & .038 & .708 \\
Highest Prof. Qualification & 348 & 1 & 4 & 1.79 & .042 & .776 \\
Teaching Experience & 348 & 1 & 4 & 2.90 & .063 & 1.172 \\
No of family members & 348 & 1 & 4 & 3.21 & .045 & .836 \\
Average Ed of family members & 348 & 1 & 5 & 2.86 & .052 & .970 \\
Monthly salary & 348 & 1 & 4 & 3.47 & .042 & .790 \\
Source of other income & 348 & 1 & 4 & 2.73 & .072 & 1.344 \\
Main motive to join teaching & 348 & 1 & 4 & 1.48 & .030 & .565
\end{tabular}




$\begin{array}{lcccccr}\text { Satisfied with salary } & 348 & 1 & 2 & 1.20 & .021 & .399 \\ \text { Salary sufficient monthly expnd. } & 348 & 1 & 2 & 1.10 & .016 & .305 \\ \text { Monthly expenditure } & 348 & 1 & 7 & 3.43 & .089 & 1.659 \\ & & & & & \\ \text { Valid N (listwise) } & 348 & & \end{array}$

Table 2 shows there were five sub-categories regarding age (21-25, 26-30, 31-35, 3640 , and 41 years or above); the mean of age stood at 4.34 indicating overall age of the respondents ranged 36- 41 years or above. A majority of the respondents were urban males while most of respondents were married. Regarding academic and professional qualifications and experience majority of them were graduates with B.Ed. and had 6-10 years of teaching experience. The sample of teachers had 4-6 children at average while their average education fell to be 4-6 years of education. Their average monthly salary was found to Pak-Rs: 21,00025,000/. Private after-school tuition and own small business/shop appeared to be the source of other income of the respondent teachers. Regarding strong motive to select the teaching profession the respondents were fairly divided to consider salary/financial benefits and respect/inner satisfaction as the main source of inspiration; however majority ( $M=1.48$ out of 2 above subcategories) were attracted to the extrinsic motives associated with teaching job. Majority were satisfied with their monthly salary and thought it was sufficient for monthly expenditure, while their monthly expenditure at average $(M=3.43)$ stood at Pak-Rs: $31,000 /$ to 45,000/.

Research Questsion-1: What is the existing level of the intrinsic motivation among public sector primary school teachers of District Hyderabad, Sindh?

The descriptive statistics regarding the level of intrinsic motivation among public sector primary school teachers is showed in Table 3 below:

Table 3

\section{Descriptive Statistics of Intrinsic Motivation Items}

\begin{tabular}{|c|c|c|c|c|c|c|c|}
\hline \multirow[t]{2}{*}{ Shortened items } & $\mathrm{N}$ & Minimum & Maximum & \multicolumn{2}{|c|}{ Mean } & \multirow{2}{*}{$\begin{array}{c}\text { SD } \\
\text { Statistic }\end{array}$} & \multirow{2}{*}{$\begin{array}{l}\text { Variance } \\
\text { Statistic }\end{array}$} \\
\hline & Statistic & Statistic & Statistic & Statistic & Std. Error & & \\
\hline Teaching gives job satisfaction & 348 & 1 & 5 & 1.65 & .031 & .585 & .343 \\
\hline Enjoy teaching as a profession & 348 & 1 & 4 & 1.62 & .032 & .588 & .346 \\
\hline Like challenging nature of teaching & 348 & 1 & 5 & 1.86 & .040 & .740 & .548 \\
\hline Teaching is a competitive profession in this school & 348 & 1 & 5 & 2.07 & .043 & .800 & .640 \\
\hline Teaching gives recognition and respect from the community & 348 & 1 & 5 & 1.81 & .039 & .731 & .535 \\
\hline Believe having career development in teaching profession & 348 & 1 & 5 & 2.18 & .052 & .961 & .923 \\
\hline Teaching responsibilities give a sense of control over others. & 348 & 1 & 5 & 1.86 & .037 & 699 & .488 \\
\hline Teaching is one of my goals in life & 348 & 1 & 4 & 1.90 & .037 & .684 & .468 \\
\hline Believe being useful to community as a teacher than other job & 348 & 1 & 5 & 1.83 & .039 & .729 & .531 \\
\hline Teaching provides interaction with people from many areas & 348 & 1 & 3 & 1.69 & .027 & .511 & .261 \\
\hline Above motivators have increased morale to work as teacher & 348 & 1 & 5 & 1.99 & .047 & .871 & .758 \\
\hline Valid N (listwise) & 348 & & & & & & \\
\hline
\end{tabular}


Table 3 reveals respondents' overall agreement of the targeted intrinsic motivational predictors. The mean scores of above 11 predictors ranges from 1.62 to 2.18 showing overall agreement throughout. The respondents agreed that teaching gave them job-satisfaction; they enjoyed and liked teaching; it provided recognition and respect from the community; it offered career development; it supported control over others; it was one of the important goals; they believed that being teacher was useful than any other job; it provided diverse interactions in community; and above predictors increased their morale to work as a teacher.

Research Question-2 What is the existing level of the extrinsic motivation among public sector primary school teachers of District Hyderabad, Sindh?

Extrinsic motivation among primary school teachers reveals availability of poor extrinsic rewards and benefits throughout; as shown blow in table 4:

Table 4

\section{Descriptive Statistics of Extrinsic Motivation Items}

\begin{tabular}{|c|c|c|c|c|c|c|}
\hline \multirow[t]{2}{*}{ Shortened Item } & \multirow{2}{*}{$\begin{array}{c}\mathrm{N} \\
\text { Statistic }\end{array}$} & \multirow{2}{*}{$\begin{array}{l}\text { Minimum } \\
\text { Statistic }\end{array}$} & \multirow{2}{*}{$\begin{array}{c}\text { Maximum } \\
\text { Statistic }\end{array}$} & \multicolumn{2}{|c|}{ Mean } & \multirow{2}{*}{$\begin{array}{c}\text { SD } \\
\text { Statistic }\end{array}$} \\
\hline & & & & Statistic & Std. Error & \\
\hline I am paid a salary that is enough to cater for my basic needs & 348 & 1 & 5 & 2.53 & .067 & 1.248 \\
\hline The school provides me free accommodation. & 348 & 1 & 5 & 3.97 & .034 & .644 \\
\hline I get free meals at school & 348 & 1 & 5 & 3.90 & .043 & .804 \\
\hline Salary payments are prompt & 348 & 1 & 5 & 2.28 & .068 & 1.262 \\
\hline The school offers weekly duty allowances & 348 & 1 & 5 & 3.95 & .034 & .634 \\
\hline Extra paid teaching allowances help me to complete the syllabus & 348 & 2 & 5 & 4.03 & .027 & .502 \\
\hline The school offers financial assistance to teachers with parties & 348 & 1 & 5 & 3.82 & .043 & .802 \\
\hline $\begin{array}{l}\text { May get advance payment from the school in case of financial } \\
\text { problem }\end{array}$ & 343 & 2 & 5 & 3.41 & .051 & .950 \\
\hline The school organizes end of year party for teachers & 348 & 1 & 5 & 3.13 & .056 & 1.045 \\
\hline Teachers who perform well are given prizes & 348 & 1 & 5 & 3.59 & .046 & .849 \\
\hline Teachers are given leave for absence when justified & 348 & 1 & 5 & 2.50 & .059 & 1.104 \\
\hline Teachers are given free medical care in case of ill health & 348 & 1 & 5 & 3.70 & .049 & .909 \\
\hline Above motivators have increased my performance as a teacher & 348 & 1 & 5 & 3.22 & .058 & 1.088 \\
\hline $\begin{array}{l}\text { Would change my profession if I could have got one better } \\
\text { rewarding. }\end{array}$ & 348 & 1 & 5 & 2.55 & .070 & 1.304 \\
\hline Valid N (listwise) & 343 & & & & & \\
\hline
\end{tabular}

Table 4 implicates respondents' either indecisiveness or disagreement of the provision of targeted extrinsic predictors of motivation i.e. provision of free accommodation, free meals at school, weekly allowances, advance payment, extra paid teaching allowances, financial assistance for celebration of new-year parties, rewards to promising/competitive teachers, and free medical treatment (Mean ranged 2.28 to 3.97); however, a few items showed overall 
positive perception of the respondents: item regarding whether respondents' monthly salaries satisfied their basic needs showed either agreement or neutral response $(M=2.53)$; same pattern was seen regarding item asking for if the respondents got leave for absence when justified $(M=2.50)$; item regarding whether monthly salaries were prompt indicated tilt towards agreement $(M=2.28)$; Interestingly, an item asking for if the respondents would change their profession if got one better rewarding job $\mathrm{M}=2.55$ showing either agreement or tilt towards being neutral. They agreed or remain indecisive whether above extrinsic predictors enhanced their morale to perform as a competent professional teacher $(M=2.55)$.

Research Question-3 What is the existing level of the performance of public sector primary school teachers of District Hyderabad, Sindh as perceived by their respective head-teachers?

The descriptive statistics reveal poor performance of the public sector primary school teachers as shown in table 5:

Table 5

Descriptive Statistics of the Teachers' Performance Items

\begin{tabular}{|c|c|c|c|c|c|c|}
\hline \multirow{2}{*}{ Shortened Item } & \multirow{2}{*}{$\begin{array}{c}\mathrm{N} \\
\text { Statistic }\end{array}$} & \multirow{2}{*}{$\begin{array}{l}\text { Minimum } \\
\text { Statistic }\end{array}$} & \multirow{2}{*}{$\begin{array}{l}\text { Maximum } \\
\text { Statistic }\end{array}$} & \multicolumn{2}{|c|}{ Mean } & \multirow{2}{*}{$\begin{array}{c}\text { SD } \\
\text { Statistic }\end{array}$} \\
\hline & & & & Statistic & Std. Error & \\
\hline Comes on time in the school/class. & 348 & 1 & 5 & 1.93 & .052 & .968 \\
\hline Comes with lesson plans in class. & 348 & 1 & 5 & 3.69 & .057 & 1.069 \\
\hline Conducts students' achievement tests. & 348 & 1 & 5 & 2.80 & .055 & 1.032 \\
\hline Actively participates in co-curricular activities & 348 & 1 & 4 & 2.75 & .049 & .914 \\
\hline Timely assesses students tests \&gives supporting feedback & 348 & 1 & 5 & 2.90 & .050 & .928 \\
\hline Takes interest in school affairs and fulfils his/her responsibilities. & 348 & 1 & 5 & 2.74 & .052 & .962 \\
\hline Takes/maintains regular attendance of the students & 348 & 1 & 4 & 2.49 & .055 & 1.023 \\
\hline Teaches through learner-friendly teaching methods and resources & 348 & 1 & 5 & 3.27 & .046 & .863 \\
\hline Uses physical punishment to control students or maintain discipline & 348 & 1 & 5 & 2.73 & .056 & 1.041 \\
\hline Checks students' nails and ensures their cleanliness. & 348 & 1 & 5 & 1.98 & .052 & .963 \\
\hline Gives related home-work to strengthening students' learning. & 348 & 1 & 4 & 2.19 & .055 & 1.026 \\
\hline Covers the total prescribed course in an academic year. & 348 & 2 & 5 & 3.97 & .039 & .722 \\
\hline The overall performance of the teacher in this school is good. & 348 & 1 & 5 & 3.21 & .049 & .920 \\
\hline Valid N (listwise) & 348 & & & & & \\
\hline
\end{tabular}

Table 5 shows overall descriptive statistics of the performance as perceived by the head-teachers of their respective teachers shows disappointing figures; responses to most of the items either fell at neutral or disagreement of the targeted indicators of the performance. The overall mean ranged from 1.93 (agreement) to 3.97 (disagreement). Regarding agreement only two items can be seen item number 1 (the teacher comes on time) and 10 (the teacher checks students' nails and ensure their cleanliness). Regarding disagreement three items corresponded to disagreement of required performance of the teachers: item asking for if the teachers came fully prepared i.e. came with lesson plans got mean score of 3.69 at 
Likert scale options; similarly, a clear disagreement $(M=3.97)$ was perceived by the headteachers regarding whether the teachers covered total prescribed course in an academic year; and whether they taught through learners-friendly teaching methods and resources got mean score of 3.27 which related to neutral if not clear disagreement. The most items corresponded to head-teachers' neutral or indecisive degree of agreement or disagreement about their respective teachers' performance regarding conducting students' tests $(M=2.80)$, participating in co-curricular activities $(M=2.75)$, timely assessing students' tests and giving supporting feedback $(M=2.90)$, taking interest in school affairs and fulfilling assigned responsibilities $(M=2.74)$, taking daily students' attendance $(M=2.49)$, using physical punishment to students for maintaining discipline $(M=2.73)$, and giving topic related homework to students $(M=2.19)$.

Research Question-4 How can we improve the performance of public sector primary school teachers?

The data was collected following through open-ended questions of the questionnaires:

1. What problems do you face as a teacher in this school?

2. What do you think can be done to improve teacher performance in this school?

3. What do you think can be done to improve teacher motivation in this school?

The respondent teachers' responses best fit in following themes and related subthemes to uplift teachers' motivation and performance through open-ended related question:

\section{Theme 1. Related to Physical Facilities}

- Government should provide basic infrastructure i.e. proper building/classrooms, drinking water, toilets, desks, chairs, roads and other basic facilities at every school.

\section{Theme 2. Related to Political Influence}

- Teachers' appointment must be made on pure merit through public service commission or reputable organization.

- There should be no political interference in teachers' transfer and postings; they should be contingent based to overcome any imbalance or shortage/excess of teachers. Theme 3. Related to Professional Trainings

- Existing professional trainings especially pre-service programs i.e. primary teaching certificate (PTC), certificate in teaching (CT), bachelor of education (B.Ed.), master of education (M.Ed.) are no more helpful in inculcating professional teaching competencies therefore their curricula, examination, and teaching process should be revised.

- Existing teachers simply lack in proper professional pedagogical content knowledge and related skills for all subjects therefore proper refresher short courses or in-service trainings are must for all existing teachers to properly teach new curricula.

\section{Theme 4. Related to Rewards and Recognition}

- More monetary benefits i.e. rewards and recognition for encouraging competent students and teachers should be ensured

- Performance based rewards and promotions

- Fixed but sound salary package (i.e. Pak Rs: 50,000/ per month salary) be introduced

- Free medical facilities be extended to teachers and head-teachers

- Reward and punishment is must in all fields (transparent system encourages teachers' motivation and performance)

- Advance increments on account of higher qualification i.e. B.Ed., M.Ed., M.Phil., and $\mathrm{PhD}$ which are either frozen or not accorded should be revived or introduced.

Theme 5. Related to Supervision 
- Separate cadre for supervisors be introduced; they should be appointed on merit through NTS testing regarding professional content knowledge and skills with better pay-scales so that they may not receive any bribe/amount for fuel from head-teachers.

\section{Theme 6. Collaboration and Cooperation}

- Team-work between/among teachers, head-teachers, and higher ups is simply lacking which must be ensured.

- In our public sector institutions mostly autocratic mode of administration prevails which should be replaced with democratic and participative one.

\section{Theme 7. Administration}

a) Administration cadre should be separated and related post should be filled through public service commission examination.

\section{Discussion}

Present study's findings are more or less in agreement with the study of V. Results of present study also revealed: teachers' performance is disappointing due to low salaries and other extrinsic benefits, political interference, little or no monitoring/accountability, poor learning material and process i.e. multi-grade teaching, and teaching as a second/last choice. Similarly a survey (YesPakistan.com) found low salaries, low preference for choosing teaching as a career, poor working conditions, poor basic facilities and school buildings, ghost schools and teachers, and no or poor accountability on teachers contribute toward poor motivation of primary school teachers of Pakistan (YesPakistan.com, 2012).

A relatively recent study of Salma and Sajid (2012) also concluded that teachers of Kotli (Azad Jamu Kashmir District) were low-motivated and dissatisfied with their job. The study pointed out crucial factors causing low motivation and dissatisfaction of teachers: teachers were commonly dissatisfied with income, salary, and promotion criteria; teachers were also afraid of political involvement in their recruitments, postings and transfers; larger class size (too much students); poor accountability and administration undermined jobsatisfaction of teachers at secondary schools. Though this study did not involve secondary school teachers; however, similar situation exists in the context of primary school teachers of Hyderabad (Sindh) with exact same situation.

Present findings are in harmony with findings of the most recent study of Bhutto (2014) though involved secondary school teachers. It has found through respective students that their teachers neither planed for their lessons nor did cover the prescribed course (almost half the course remained untouched). Above study was conducted in District Jamshoro, Sindh which is neighboring district to Hyderabad where present study was conducted. Both findings are in total agreement however involving primary school teachers of Hyderabad.

Nasser ud Din, Tufail, Shereen, Nawaz, and Shahbaz (2012) surveyed through very small sample of 40 secondary school teachers of Kohat, Pakistan about the factors affecting motivation in rendering prescribed teaching services. Through measures of central tendency the authors found that financial (extrinsic or tangible factors) rewards and incentives stood primary contributors toward teachers motivation; on the other hand, the socio-status, examination-stress, and teaching as a first choice relatively less affected teachers' motivation. They recommended compensative sound salary package for public sector teachers (p. 442443). Present study dealt with the topic in relatively comprehensive and better way because it involves descriptive, regression, and t-test analyses with an appropriate sample size which were lacking in above study; however, besides other things, it confirms the dominating effect of extrinsic motivators which were missing in our (Sindh's) context.

This study's findings more or less agree to the findings of related studies at our local and national context; however its findings along with other studies disagree to the findings of 
related studies conducted in abroad especially in the context of developed countries where they find that intrinsic motivation is the dominant factor (if not only) contributing to teachers' performance as compared to extrinsic motivation which undermines teachers' intrinsic motivation and performance, at least in the long run (Deci, Koestner, \& Ryan, 2001); Benabou and Tirolem (2003) also concluded that "Incentives are then only weak reinforcers in the short run, and negative reinforcers in the long run” (p. 489). In this regard, the researcher thinks that justification of present findings lie in Maslow's hierarchy of needs i.e. satisfaction of lower level needs leads to broader thinking and working for broader goals of humanity and services. Here, according to findings of present study teachers are not well paid, even they struggle for making both ends meet and look additional part-time job for compensating their monthly expenditure.

\section{Conclusions}

This study aimed at studying the level of public sector primary school teachers' (PSTs) motivation (intrinsic and extrinsic) and their performance assessed through their respective head-teachers in the context of District Hyderabad, Sindh.

Regarding intrinsic motivation, it was found that respondents' self-perceived motivation corresponded to overall agreement of the 11 targeted predictors of intrinsic motivation. The mean scores of above 11 predictors ranges from 1.62 to 2.18. However, regarding extrinsic motivation, the respondents either remained neutral or disagreed against targeted 14 statements (Mean ranged 2.50 to 3.97). It explicitly confirms that intrinsic motivation is not dependent on extrinsic motivators i.e. salary and other tangible rewards.

On the other hand, it seems that respondents exaggerate about their perceived intrinsic motivation because greater intrinsic motivation surely results in better/greater performance, but here the case is not so, even it is contrasting because descriptive statistics of their performance reveal disappointing picture. Almost all (except the first two out of 13) responses to performance statements (assessed by their respective head-teachers) either fall to be neutral or correspond to disagreement. The mean of means of performance items stand at 2.92 which clearly correspond to neutral/undecided degree of agreement; it provides substantial ground that the teachers exaggerated about their perceived intrinsic motivation.

Almost all (except the first two out of 13) responses to performance statements (assessed by their respective head-teachers) either fall to be neutral or correspond to disagreement. The mean of means of performance items stand at 2.92 which clearly correspond to neutral/undecided degree of agreement. This situation in obviously disappointing one and can be related to poor extrinsic motives provided to the teachers (their mean ranged from 2.50 to 3.97 with mean of total related means 3.33). It reveals that overall effect of motivation accounted for $29.9 \%$ variation in respondents' performance with dominating effect of extrinsic motivators.

This study's findings more or less agree to the findings of related studies at our local and national context; however its findings along with other studies disagree to the findings of related studies conducted in abroad especially in the context of developed countries where they find that intrinsic motivation is the dominant factor (if not only) contributing to teachers' performance as compared to extrinsic motivation which undermines teachers' intrinsic motivation and performance, at least in the long run (Deci, Koestner, \& Ryan, 2001); Here, according to findings of present study teachers are not well paid, even they struggle for making both ends meet and look additional part-time job for compensating their monthly expenditure. 


\section{REFERENCES}

Alderfer, C. P. (1969). An empirical test of a new theory of human needs. Organizational Behavior and Human Performance, 4, 143-175.

Amin, M.E. (2005). Social science research conception, methodology and analysis. Kampala, Makerere University Printery.

Analoui, F (2000). What motivates senior managers? The case of Romania. Journal of Managerial Psychology, 15(4), 324-340.

Aslam, M., Jamil, B. R., Rawal, S. (2011). Teachers and school quality: Some policy pointers from rural Punjab. S.A.F.E.D. (South Asian Forum for Education Development): Lahore, Pakistan. Retrieved from www.safedafed.org

Atta, M. A., Jamil, A. (2012). Effects of motivation and parental influence on the educational attainments of students at secondary level. Academic Research International, 2(3), 427-431. Retrieved from http://www.savap.org.pk/journals/ARInt./Vol.2(3)/2012(2.352).pdf

Bennell, P (2004). Teacher motivation and incentives in Sub-Saharan Africa and Asia. Knowledge and Skills for Development, Brighton, July 2004

Bhutto, M. I. (2011). Effects of social reinforcers on students' learning outcomes at secondary school level. International Journal of Academic Research in Business and Social Sciences, 1(2), 71-86. Retrieved from http://www.hrmars.com/admin/pics/50.pdf

Deci, E. L. (1980). The psychology of self-determination. Lexington, MA: Heath.

Deci, E. L., Koestner, R., \& Ryan, R. M. (1999). A meta-analytic review of experiments examining the effects of extrinsic rewards on intrinsic motivation. Psychological Bulletin, 125, 627-668.

Deci, E. L., Koestner, R., \& Ryan, R. M. (2001). Extrinsic rewards and intrinsic motivation in education: Reconsidered once again. Review of Educational Research, 71(1), 1-27. Retrieved from www.selfdeterminationtheory.org/SDT/.../2001_DeciKoestnerRyan.pdf

Eyal, O. \& Roth, G. (2011). Principals' leadership and teachers' motivation: Selfdetermination theory analysis. Journal of Educational Administration,(49)3, 256-275. doi: $\underline{10.1108 / 09578231111129055}$

Hamner, W.C., \& Hamner, E.P. (1976). Behavior modification and the bottom line. Organizational Dynamics, 4 (4), 3-21.

Hornby, A., S. (2000). Oxford Advanced Learner's Dictionary of Current English. Oxford University Press.

Komaki, J. (1982). Managerial effectiveness: Potential contributions of the behavioral approach. Journal of Organizational Behavior Management, 3, 71-83. 
Maslow, A.H. (1943). A theory of human motivation. Psychological Review, 50, 370-396.

Nadim, M., Chaudhry, M. S., Kalyar, M. N., \& Riaz, T. (2012). Effects of motivational factors on teachers' job satisfaction: A study on public sector degree colleges of Punjab, Pakistan. The Journal of Commerce, 4(4), 25-32. Retrieved from http://joc.hcc.edu.pk/articlepdf/joc201214_25_32.pdf

Nasser Ud Din, M., Tufail, H., Shereen, S., Nawaz, A., \& Shahbaz, A. (2012). Factor affecting teacher motivation at secondary school level in Kohat city. Interdisciplinary Journal of Contemporary Research in Business, 3(10), 442-449.

Okumbe, J.A. (1998). Educational management theory and practice. Nairobi University press, Nairobi, Kenya.

Ryan, R. M. \& Deci, E. L. (2001). Intrinsic and extrinsic motivations: Classic definitions and new directions. Contemporary Educational Psychology 25,54-67. doi:10.1006/ceps.1999.1020

Salma, G. \& Sajid, M. A. (2012). Teacher's motivation and job satisfaction. International Journal of Management Sciences and Business Research, 1(10), 56-65. Retrieved from http://www.ijmsbr.com/Volume\%201,\%20Issue\%2010\%20(5).pdf

Sansone, C., \& Harackiewicz, J.M. (2000). Intrinsic and extrinsic motivation: The search for optimal motivation and performance. San Diego: Academic Press.

Save the Children (2011). Teacher motivation: Theoretical framework, situation analysis of save the children country offices, and recommended strategies. By Jarret Guajardo under Save the Children Basic Education Intern, Spring 2011. Retrieved from http://www.oxfamnovib.nl/Redactie/Downloads/English/SPEF/28124\%20Teacher\%20Motivation\%20Report.pdf

Skinner, B .F. (1976). About Behaviorism. New York: Vintage Books.

Stone J. R. (1998). Human resource management. Brisbane Jacaranda (3rd Ed). Wiloy Ltd. Synthesis report on a sub regional workshop and four country monograph (1998).

White, R. (1959). Motivation reconsidered: The concept of competence. Psychological Review, 66, 297-333. 